\title{
Soil microorganisms at the windthrow plots: the effect of post- disturbance management and the time since disturbance
}

\author{
Erika Gömöryová( ${ }^{(1)}$ \\ Peter Fleischer ${ }^{(1-2)}$, \\ Viliam Pichler ${ }^{(1)}$, \\ Marián Homolák ${ }^{(1)}$, \\ Richard Gere ${ }^{(1)}$, \\ Dušan Gömöry ${ }^{(1)}$
}

\begin{abstract}
Wind disturbance is a major natural driver of forest dynamics in a large part of Europe and can affect soil properties in different ways and for different time. The present study focuses on the effects of post-disturbance management of windthrow plots in the Tatra Mountains, Slovakia, on soil microorganisms ten years after the disturbance. Their comparison with the microbial characteristics at a new windthrow plot caused by strong wind in 2014 was also carried out. Three research plots differing in the way of their management after the windstorm in 2004 (EXT, salvage plot; FIR, salvage plot affected by fire; NEX, unsalvaged plot) and the plot destroyed by strong wind in May 2014 (REX) were used for study. Ten soil samples were taken from the mineral A-horizon (depth: $0-10 \mathrm{~cm}$ ) at each plot in autumn 2014. In soil samples, soil chemical and microbial characteristics (microbial biomass C, basal and substrate-induced respiration, $\mathrm{N}$-mineralisation, catalase activity, richness and diversity of soil microbial functional groups based on the Biolog approach) were determined. Ten years after the disturbance we still observed significant differences in microbial characteristics between FIR and the other plots, with higher microbial activity at the FIR, while no significant differences were found among the other plots. The results indicate that at a higher altitude the effect of fire on soil microorganisms is more distinct than removing or not removing of fallen trees and persists even over a decade.
\end{abstract}

Keywords: Forest Soil, Soil Microorganisms, Windthrow, Fire, Postdisturbance Management

et al. 2016). Trees and forest stands are known to influence soil and its properties in various ways, e.g., through above- and belowground input of organic sources (often differing in their quantity and quality), as well as water and nutrient uptake by plant roots, differences in microclimate, stemflow, pit-and-mound formation after windthrow (Ulanova 2000, Thürig et al. 2005). Changes in the herb layer (damage by fallen trees, invasion of non-indigenous species etc.) and regeneration of trees after the disturbance may also modify the soil (Bormann et al. 1995). Therefore, canopy loss due to natural disturbances (windthrow) or management (clear-cutting) may distinctly influence site conditions and consequently change soil proper-
(1) Technical University in Zvolen, Faculty of Forestry, T. G. Masaryka 24, SK-960 53 Zvolen (Slovakia); (2) Research Station and Museum of the Tatra National Park, SK-05960 Tatranská Lomnica (Slovakia)

@ Erika Gömöryová (gomoryova@tuzvo.sk)

Received: Dec 11, 2016 - Accepted: Mar 17, 2017

Citation: Gömöryová E, Fleischer P, Pichler V, Homolák M, Gere R, Gömöry D (2017). Soil microorganisms at the windthrow plots: the effect of post-disturbance management and the time since disturbance. iForest 10: 515-521. - doi: 10.3832/ifor2304-010 [online 2017-04-20]

Communicated by: Rupert Seidl ties (Reinhart et al. 2010, Hartmann et al. 2016), mainly in the top soil horizons.

Changes in water and temperature regimes, nutrient leaching, chemical properties and specific processes such as perturbation caused by uprooting, erosion, etc. have been primarily studied up to now (Robertson et al. 1993, Ulanova 2000, Kooch et al. 2014). Changed environmental conditions on the affected areas are expected to result in changed microhabitat conditions for living organisms (Bormann et al. 1995, Ulanova 2000, Certini 2005, Kooch et al. 2014) and, consequently, to be reflected in different responses of soil organisms. However, information about soil biota on windthrow-affected areas especially in longterm is scarce (Wright \& Coleman 2002, Cerevková et al. 2013, Urbanovičová et al. 2014).

In November 2004, over 12,000 ha of forest stands in the Tatra Mountains (Slovakia, Central Europe) were broken or uprooted by strong wind. After this event, monitoring of changes in soil properties started at the long-term research plots with different post-disturbance management (salvage cutting, no interference) established by the Research Station of the Tatra National Park. Ten years later, in May 2014, the forest stand which served as a reference plot until that time, was destroyed by another strong wind event. Windthrow areas are usually salvaged; har- 
vesting of disturbed stands is practiced for the sanitary and economic reasons and to prevent fires whose number increases as a result of extremely hot and dry periods associated with the ongoing climate change. However, in other areas (e.g., protected areas and nature reserves) the fallen trees are retained on site (Köster et al. 2005). As the environmental conditions at plots with different post-disturbance regime differ, changes in plant cover and soil properties are expected. Shortly after the disturbance, changes in microbial biomass and/ or activity are often observed (Tscherko \& Kandeler 1999, Nielsen \& Winding 2002). Also in the Tatra Mts. we found changes in the soil microbial activity and biomass during the first years after the disturbance (Gömöryová et al. 2011).

After a disturbance, environmental conditions at the windthrow plots are gradually changing with the formation of a new forest through the ongoing plant succession and trees regeneration. Such changes can be reflected in the responses of soil microbiota to varying degrees at the plots. The objective of this study was to assess the responses of soil microorganisms to wind disturbance 10-years after the event and find whether different post-disturbance management regimes on the windthrow area are reflected in different responses of soil microbiota after a decade. At the same time, the newly disturbed forest (a control plot formerly) would add useful information on windthrow effects directly after a disturbance event and on possible differences in soil microbial responses between "new" and "old" windthrow plots. Understanding the microbial processes in the long-term and their responses to different management regimes may help in the choice of appropriate forest practices regarding the potential nutrient availability for later tree growth, since soil microbiota is the key player in nutrient cycles and nutrient accessibility for plants.

\section{Materials and methods}

\section{Site description}

The study was performed at the research plots established in 2005 in the windthrow area of the Tatra National Park situated at an altitude of 1040-1260 m a.s.l. with SE-S aspect and slope of 5-10\%. The dominant soil type is Dystric Cambisol formed mostly from moraine material. Four research plots with area of 100 ha each and with different management regime were surveyed (Fleischer 2011):

1. REX - former reference plot established in an intact forest stand and destroyed by strong wind in May 2014. Canopy was reduced to approx. $15 \%$. At the time of soil sampling, most of fallen trees were not removed from the plot yet. Until the disturbance the plot was covered by a $>120$-year-old forest stand of Norway spruce (Picea abies Karst., 80\%) with an admixture of larch (Larix decidua Mill.,
$20 \%$ ) and served as a control plot unaffected by wind. Vaccinium myrtillus, Avenella flexuosa, Oxalis acetosella and several mosses are the most widespread understory plants at this plot. During the last 10 years, the herb layer has not significantly changed.

2. EXT - plot with salvage logging, fallen trees were removed from the plot after the windthrow in 2004. At the plot the vegetation composition differs significantly from the former one. Since 2007 Calamagrostis villosa and Chamaenerion angustifolium have become the most common species; the plot was reforested by Picea abies, Pinus cembra, Larix decidua, Fagus sylvatica and Acer pseudoplatanus.

3. FIR - fire plot, fallen trees were extracted from the plot; however, in summer 2005 the plot was destroyed by a wildfire and the surface organic layer was mostly burnt. Since 2007 C. angustifolium and Rubus ideaus became dominant and since 2010 also C. villosa and C. arundinacea appeared more frequently; the plot was reforested with the same species as EXT.

4. NEX - not extracted, windthrow plot without any intervention, left to spontaneous succession; $C$. villosa and $A$. flexuosa dominated the first year after the windstorm, C. angustifolium became dominant in 2011 and R. idaeus in 2012. Intensive natural regeneration of trees (Picea abies, Sorbus aucuparia, Salix caprea and Betula pendula) is ongoing at the plot.

\section{Soil sampling and analyses}

In autumn 2014, soil samples were taken in each plot at $10 \mathrm{~m}$ intervals along a $90 \mathrm{~m}$ long transect from the depth of 0-10 cm (excluding the surface organic layer). Herb layer (cover percentage and number of species) was recorded around the sampling places.

Immediately after bringing samples to the laboratory, each sample was divided into two parts. One part was intended for microbial analyses, as well as moisture and dry mass assessment, and was stored in a refrigerator at $4{ }^{\circ} \mathrm{C}$ until the analysis. The other part was air-dried and used for measurements of soil chemical properties.

Moisture and dry weight were determined gravimetrically by oven-drying fresh soil at $105{ }^{\circ} \mathrm{C}$ for 24 hours. Soil acidity was measured potentiometrically in $1 \mathrm{M} \mathrm{KCl}$ suspension ( $20 \mathrm{~g}$ soil plus $50 \mathrm{ml} \mathrm{KCl}$ solution) after $24 \mathrm{~h}$. For the determination of total carbon $(\mathrm{C})$ and nitrogen $(\mathrm{N})$ concentration MACRO Elemental Analyzer ${ }^{\circledast}$ (CNS Version, Elementar Gmbh, Langenselbold, Germany) was used, employing the dry combustion method.

Soil microbial biomass $\mathrm{C}$ was estimated according to Islam \& Weil (1998) using the microwave-irradiation procedure. C concentration in the extract was quantified by oxidation with $\mathrm{K}_{2} \mathrm{Cr}_{2} \mathrm{O}_{7} / \mathrm{H}_{2} \mathrm{SO}_{4}$ and titrimetri- cally by $\left(\mathrm{NH}_{4}\right)_{2} \mathrm{Fe}\left(\mathrm{SO}_{4}\right)_{2}$. Basal soil respiration was measured by estimating the amount of $\mathrm{CO}_{2}$ released from fresh soil after $24 \mathrm{~h}$ incubation at $21^{\circ} \mathrm{C}$ and absorbed in $0.05 \mathrm{M} \mathrm{NaOH}$. The amount of carbonate was determined by titration with $0.05 \mathrm{M}$ $\mathrm{HCl}$ after the precipitation of carbonates by $0.5 \mathrm{M} \mathrm{BaCl}_{2}$. For the determination of substrate-induced respiration, soil samples were amended by $1 \%(\mathrm{w} / \mathrm{w})$ glucose and $\mathrm{CO}_{2}$ evolved was measured as described above after $4.5 \mathrm{~h}$ (Alef 1991). N-mineralisation was determined by anaerobic incubation according to Kandeler (1993). Catalase activity was measured 10 min after $3 \% \mathrm{H}_{2} \mathrm{O}_{2}$ was added to fresh soil sample based on the volume of discharged oxygen, according to the method of Khaziev (1976). For the study of soil microbial community structure, BIOLOG EcoPlates (Insam 1997) were used. Inocula were prepared by resuspending fresh soil in $0.9 \% \mathrm{NaCl}$, the supernatant was diluted 1:10,000, and 150 $\mu$ of extract were incubated in microtitration plates at $27^{\circ} \mathrm{C}$ for 6 days. Absorbance at $590 \mathrm{~nm}$ was recorded every $12 \mathrm{~h}$ using the Sunrise Microplate Reader ${ }^{\circledR}$ (Tecan, Salzburg, Austria). Absorbance values were blanked against the control well. Metabolic activity was calculated as the area below the time-absorbance curve, and was used as a measure of abundance of the respective functional group. The richness of the soil microbial community was assessed as the number of substrates with non-zero response. For the estimation of diversity, the Hill's diversity index (Div) was calculated (Hill 1973-eqn. 1):

$$
D i v=\frac{1}{\sum p_{i}^{2}}
$$

where $p_{\mathrm{i}}$ is the frequency (relative abundance) of the $i$-th functional group.

\section{Data evaluation}

All results were expressed as dry mass. To account for the effect of the available resources on the microbial community, microbial carbon and basal respiration were also recalculated per unit of total organic carbon ( $\mathrm{Cmic} / \mathrm{C}$, resp. Resp/C). Metabolic quotient $\left(\mathrm{qCO}_{2}\right)$ was determined based on the microbial respiration and microbial biomass carbon (Resp/Cmic).

All statistical treatments of data were done using the statistical package SAS/ STAT $^{\oplus}$ (SAS 2010). Differences in soil physico-chemical properties among plots were tested using one-way analysis of variance (proc ANOVA). As biological soil properties may potentially be influenced by soil moisture, covariance analysis was used to test the effects of plot, taking moisture as a continuous covariate (proc GLM). Pairwise differences between plot means were tested by the Tukey-Kramer test.

Because microbial richness and diversity do not completely explain how the composition of functional groups of microorganisms is related to different management, a multivariate analysis was performed. We 
chose a direct gradient analysis (redundancy analysis - RDA), which allows to determine the environmental variables that best explain the changes of the frequency distributions of microbial functional groups with different management. RDA is based on a linear approximation of the species' response to environmental gradients (appropriate for a short gradient length) and yields constrained ordination axes reflecting the direction of maximum variability within the dataset which can be explained by the assessed environmental factors (Ter Braak \& Smilauer 2002). The significance of environmental variables and RDA axes was tested using Monte Carlo permutation test (9999 runs). Unrestricted permutations were employed, since the abundance of microorganisms and the composition of microbial communities generally change at very short distances, so that we did not expect spatial dependence at the scale used in this study. Significant environmental variables were identified by forward selection. The software package CANOCO (Ter Braak \& Smilauer 2002) was used for the calculations.

\section{Results}

Ten years after the disturbance, significant differences in some soil properties between plots were still evident (Tab. 1). Among soil physico-chemical properties, distinct differences were found in soil acidity and especially $\mathrm{C} / \mathrm{N}$ ratio. The REX plot exhibited the highest acidity ( $\mathrm{pH}-\mathrm{KCl} 3.19)$ whereas at the other plots the average values did not drop below pH-KCl 3.49 (Fig. 1). The lowest $\mathrm{C} / \mathrm{N}$ ratio was found at the EXT plot, while the other plots exhibited higher $\mathrm{C} / \mathrm{N}$ ratio (average $\mathrm{C} / \mathrm{N}$ about 19 ). Neither $\mathrm{C}$ nor $\mathrm{N}$ concentration differed significantly between plots due to a high intra-plot variability.
Tab. 1 - Analysis of variance and covariance of soil properties (significance of F-tests). (SWC): soil water content; ( $\mathrm{Cmic}$ ): microbial biomass carbon; (Resp): basal respiration; (SIR): substrate-induced respiration; (Nmin): N-mineralisation; (Catal): Catalase activity; (Richn): richness of soil microbial functional groups; (Div): diversity of soil microbial functional groups; ( $\mathrm{Cmic} / \mathrm{C}$ and Resp/C): microbial biomass carbon- and basal respiration-to-total carbon ratio, respectively; $\left(\mathrm{qCO}_{2}\right)$ : metabolic quotient; (df): degrees of freedom; $(*)$ : $p<0.05 ;(* *): p<0.01 ;(* * *): p<0.001 ;(n s)$ : non-significant $(P>0.05)$.

\begin{tabular}{lcccccc}
\hline Source of variation & df & SWC & $\mathrm{pH}-\mathrm{KCl}$ & $\mathrm{C}$ & $\mathrm{N}$ & $\mathrm{C} / \mathrm{N}$ \\
\hline Plot & 3 & $\mathrm{~ns}$ & $*$ & $\mathrm{~ns}$ & $\mathrm{~ns}$ & ${ }^{* * *}$ \\
Error & 36 & - & - & - & - & - \\
\hline Source of variation & df & Cmic & Resp & SIR & Nmin & Catal \\
\hline Plot & 3 & $\mathrm{~ns}$ & $* *$ & $\mathrm{~ns}$ & $* * *$ & $\mathrm{~ns}$ \\
Moisture & 1 & $* * *$ & $* * *$ & $* * *$ & $* * *$ & $* * *$ \\
Error & 35 & - & - & - & - & - \\
\hline Source of variation & $\mathrm{df}$ & Richn & Div & $\mathrm{Cmic} / \mathrm{C}$ & Resp/C & $\mathrm{qCO}_{2}$ \\
\hline Plot & 3 & $* * *$ & $\mathrm{~ns}$ & $\mathrm{~ns}$ & $*$ & $*$ \\
Moisture & 1 & $* * *$ & $\mathrm{~ns}$ & $\mathrm{~ns}$ & $\mathrm{~ns}$ & $\mathrm{~ns}$ \\
Error & 35 & - & - & - & - & - \\
\hline
\end{tabular}

The differences in microbial characteristics between plots are not consistent (Tab. 1). Among the measured characteristics, only basal respiration, $\mathrm{N}$-mineralisation and richness of microbial functional groups differed significantly between plots. Generally, the FIR plot exhibited highest microbial activity (Fig. 2 and Fig. 3), while no significant differences were found in microbial activity among the other plots. According to the results of ANOVA, microbial biomass did not differ between plots. However, Tukey-Kramer test indicates differences in Cmic between REX and EXT plots, with higher microbial biomass at the REX plot (Fig. 2). While the diversity of soil microbial functional groups did not differ between plots, the richness of functional groups was significantly lower at the REX plot in comparison to the others (Fig. 3).
Among the other microbial indices, $\mathrm{qCO}_{2}$ and Resp/C showed significant differences among different plot management, revealing a higher substrate utilisation at all "old" windthrow plots (Fig. S1 in Supplementary material).

There was neither an unambiguous trend in sample scores of the first two RDA axes, nor a clear association of any management regime with environmental variables (Fig. 4). Nevertheless, RDA scores were distributed according approximately to the naturalness of the plots: most FIR samples (i.e., samples from the most heavily damaged plot) had negative scores on the RDA 1 axis, whereas most REX samples were concentrated in the upper right corner of the graph. The community structure based on the utilisation of different carbon source showed differences especially between the
Fig. 1 - Comparison of means of the soil reaction (a), carbon (b) and nitrogen (c) concentration, and $\mathrm{C} / \mathrm{N}$ ratio (d). Homogeneous groups resulting from Tukey-Kramer test are indicated by the same letter. (REX): plot disturbed by wind in 2014; (EXT): plot disturbed by wind in 2004, salvaged; (FIR): plot disturbed by wind in 2004, salvaged, damaged by fire; (NEX): plot disturbed by wind in 2004, unsalvaged.

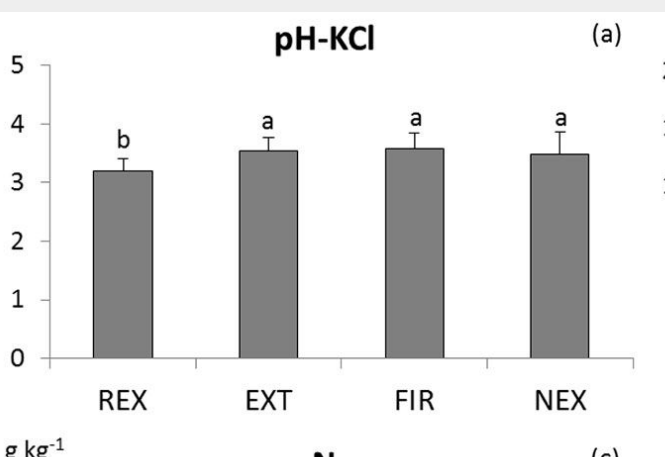

$\mathrm{g} \mathrm{kg}^{-1} \quad \mathbf{N}$

(c)

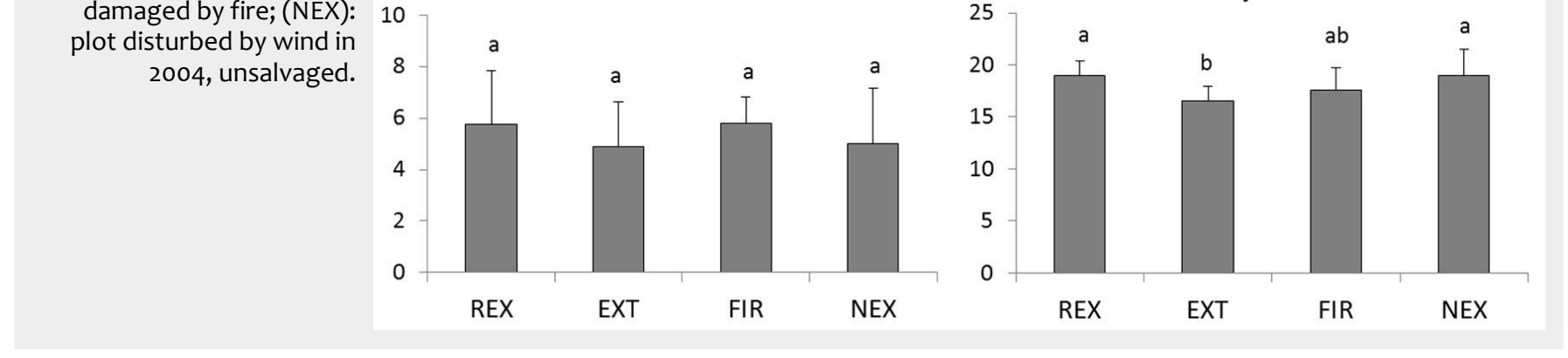

(a) $\mathrm{g} \mathrm{kg}^{-1}$

$$
200
$$$$
\begin{array}{r}
160 \\
120 \\
80 \\
40 \\
0
\end{array}-
$$

(b)

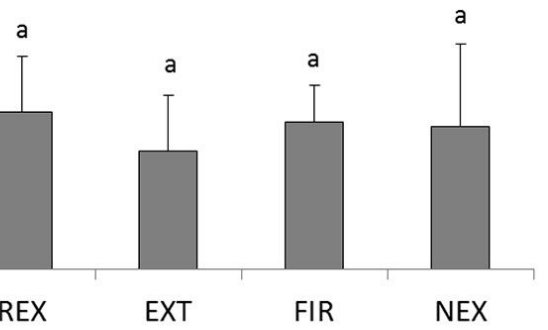

(d)

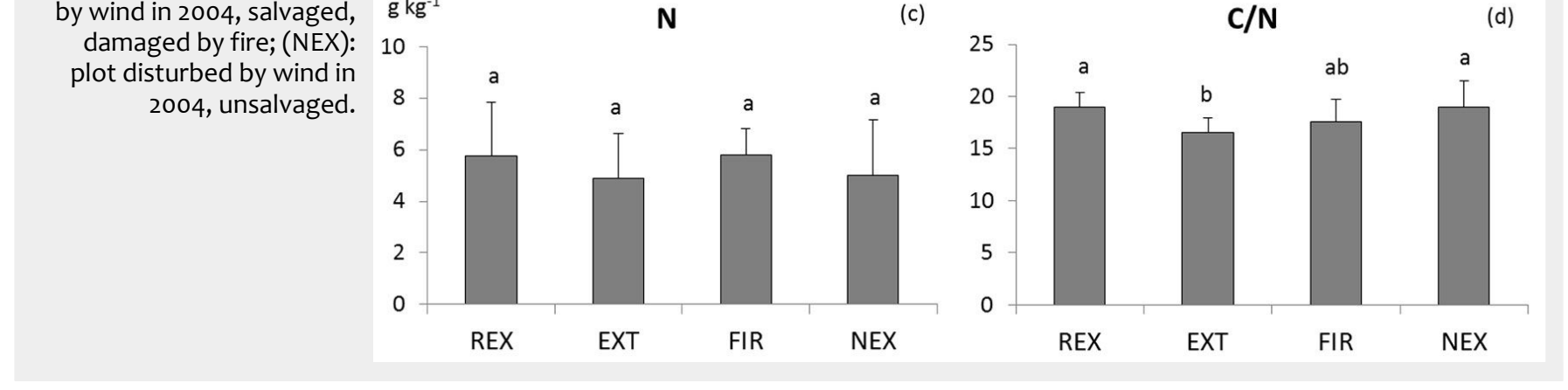



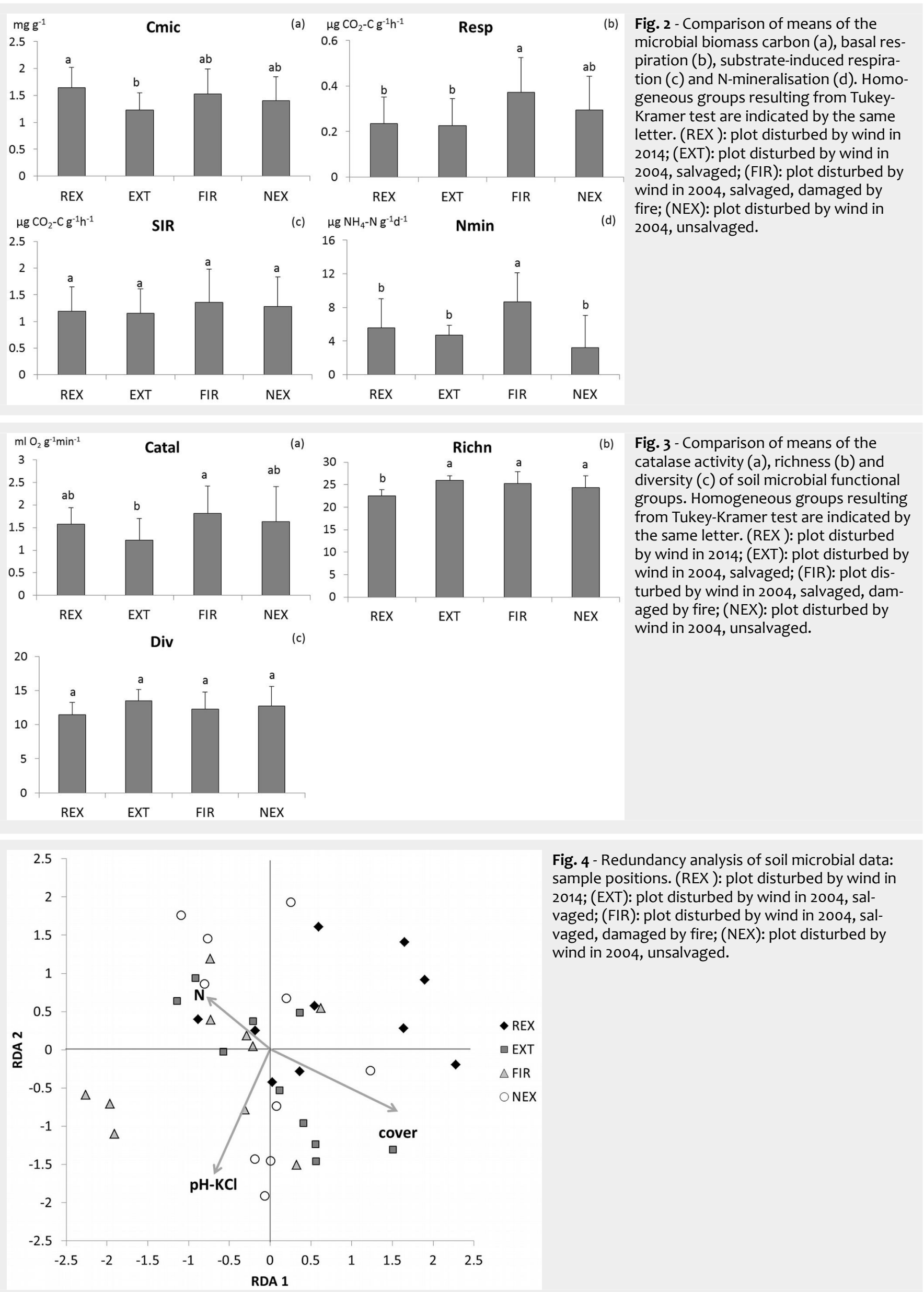

Fig. 4 - Redundancy analysis of soil microbial data: sample positions. (REX): plot disturbed by wind in 2014; (EXT): plot disturbed by wind in 2004, salvaged; (FIR): plot disturbed by wind in 2004, salvaged, damaged by fire; (NEX): plot disturbed by wind in 2004, unsalvaged. 
REX and FIR plot. At the FIR plot higher utilisation of L-arginine, L-asparagine, $\mathrm{N}$-acetyl-D-glucosamine, glycyl-L-glutamic acid and putrescine, and lower utilisation of Dglucosaminic acid was observed in comparison to the REX plot (Tab. S1 in Supplementary material).

\section{Discussion}

Analysis of soil data showed that ten years after the disturbance differences in several soil characteristics still persist between plots with different post-disturbance management. However, among soil physico-chemical properties only $\mathrm{C} / \mathrm{N}$ ratio distinctly differed between plots. Lower $\mathrm{C} / \mathrm{N}$ ratio occurred at the plots where fallen trees were extracted and thus an intensive succession of plants took place. On the other hand, higher $\mathrm{C} / \mathrm{N}$ ratio was found at the plots with persisting aboveground tree biomass. Surprisingly, the $\mathrm{C} / \mathrm{N}$ ratio at the FIR plot did not differ significantly from the REX and NEX plots, despite the fact that tree remains were extracted and similar herb layer succession was ongoing as on the EXT plot.

Environmental change after the disturbance affected soil microorganisms directly and/or indirectly. In our earlier study (Gömöryová et al. 2008), we pointed on the differences in microbial activity at the disturbed plot in comparison to the intact forest one year after the event. FIR plot exhibited the highest microbial activity, due to the reduction in thickness of the surface organic layer, the enrichment of the A-horizon by mineral nutrients released by burning, and the dissolved organic matter from the unburnt remains. Contrastingly, the response of soil microorganisms to different management on EXT and NEX plots generally did not differ, except for slower basal respiration and $\mathrm{N}$-mineralisation on the EXT plot. Later, the responses of soil microbiota to forest disturbances differed as a function of the time since disturbance. As forests recover after the disturbance, postdisturbance changes in soil microbial characteristics can diminish over time. Indeed, a significant positive relationship between time since forest harvesting and microbial biomass has been reported (Holden \& Treseder 2013). Hedo et al. (2015) found that 17 years after fire there were no differences in microbiological soil properties and enzyme activities of soil between burned and thinned, burned and unthinned, and mature plots, because total vegetation recovery normalises post-fire soil microbial parameters; thus wildfire and post-fire silvicultural treatments are not significant factors affecting soil properties after 17 years. The effect of disturbance on soil microbial communities can persist until aboveground vegetation re-grows (Hart et al. 2005). During the course of vegetation succession, changes in environmental conditions are expected to continue because of gradual changes in plant cover, but their extent and direction are difficult to predict. Rum- baitis Del Rio (2006) showed that understory vegetation composition and diversity in blowdown areas stabilized during the 5 years following the blowdown as compared with control areas, but vegetation cover continued to increase. Lang et al. (2009) found that 25 years after the disturbance, tree basal area, sapling density, shrub layer density and seedling cover converged between unsalvaged and salvaged areas; on the other hand, salvaged forest displayed significantly higher herb richness and cover, and a greater dominance of understory species benefiting from disturbance. In this study, ten years after the disturbance, still the FIR plot significantly differed from the others, showing a higher microbial activity. However, unlike the first year after the disturbance (Gömöryová et al. 2008), differences between NEX and FIR seem to vanish as no significant differences were found in microbial characteristics (except $\mathrm{N}$-mineralisation) between these plots. Fire usually leads to a decrease of soil biomass and activity because of the extremely high surface temperature during the burning (Certini 2005), making the conditions for soil microbiota unfavourable. However, the impact of fire on soil microbial biomass and activity is significantly influenced by fire severity, intensity and duration, soil moisture and also soil depth (Certini 2005, Holden et al. 2016). It was shown that intense fire with short duration does not affect more than few centimetres below the soil surface. Moreover, burnt aboveground biomass often offers a remarkable increase in the availability of nutrients (Certini 2005); thus their release into the mineral horizons could improve conditions for soil microorganisms, resulting in a higher microbial activity and biomass at the FIR plot and persisting over a decade. Also herbs can play an important role in post-disturbance trend. According to a literature review (Certini 2005), when plants promptly recolonise the burnt area, the pre-fire level of most soil properties can be recovered and even enhanced. At the FIR plot the vegetation cover reached $100 \%$ already 2 years after fire, with Chamaerion angustifolium as the dominant species (Homolová et al. 2015).

Post-disturbance treatments may cause changes in soil properties. Fleischer (2011) confirmed temporal changes in soil temperature and moisture on sites with different disturbance regimes. Peterson \& Leach (2008) found that salvaged areas had significantly greater variety of microsites, higher soil temperature and greater canopy openness on comparison to unsalvaged areas. Studies on soil microorganisms at plots cleared and not-cleared after windthrow are scarce (Köster et al. 2011). More studies are related to clear-cut and partially cut plots, which could be roughly compared with post-windthrow treatments. As shown by Holden \& Treseder (2013), while forest clear-cutting had a significant negative impact on soil micro- organisms, partial harvesting did not significantly affect soil microbial biomass. Even ten years after the disturbance, we did not confirm any differences in microbial characteristics between the salvaged and unsalvaged plots, in spite of the fact that they differed in the above-ground biomass (dead biomass of fallen trees), herb layer cover and microclimate. Surprisingly, no significant differences were found also between the REX plot (new windthrow plot) on one side and the EXT and NEX plots (old windthrow plots) on the other side. The lack of differences indicate that at higher elevations, on soil with a low $\mathrm{pH}$ and a high carbon stock, the influence of mesoclimate on soil microorganisms is more important than the differences in environmental conditions (microclimate, herb layer etc.) caused by different postwindthrow management. As mentioned above, the REX plot served as a control plot until the disturbance in 2014. As the reference (control) plot became itself wind-damaged and no other plot fulfilling the criteria of reference plot was found, it was not possible to evaluate the impact of the "new" and "old" windthrow on soil microorganisms in contrast to intact forest. Positive as well as negative effects of natural disturbances on belowground diversity were observed depending on the time since disturbance (Certini 2005, BárcenasMoreno et al. 2011, Cerevková et al. 2013, Urbanovičová et al. 2014). Meta-analysis of the disturbance effect on species richness performed by Thom \& Seidl (2015) showed that species richness increases by $35.6 \%$ on average for a high-severity disturbance event. At the windthrow plots of the Tatra Mts. only the REX plot differed significantly in the richness of soil microbial functional groups from the others. Community structure based on the utilisation of different carbon sources showed differences especially between the REX and FIR, i.e., the freshly disturbed plot and the most affected "old" plot, respectively. Even though there is no one-to-one relationship between the functional and taxonomical groups of microorganisms, this supports the suggestion that the composition of microbial community is driven by the plant community composition (Wardle et al. 2004). Knelman et al. (2015) highlighted an important role of plant colonization in succession by a clear connection between plant and bacterial communities in a postfire landscape. Different plant species produce litter and exudates in different quality varying in their degree of stimulation for soil microorganisms (Hart et al. 2005). Since the windthrow, the aboveground input of herbaceous litter with higher $\mathrm{N}$ and lower lignin content increased and the deposition of acid spruce needles decreased at the disturbed plots in comparison to the newly formed windthrow plot in the Tatra Mts., which was also reflected in a lower soil C/N ratio. Moreover, the FIR plot was enriched by the ash from the 
burnt litter in comparison to the other plots, which could differentiate the microbial community structure at this plot from the others. The fact that the shifts in nutrient availability may drive microbial community succession was confirmed by Knelman et al. (2014). As the aboveground standing plant biomass increases through time after disturbance, changes can be expected until the mature stage of forest is reached. However, information about the changes of soil microbial community structure at post-disturbance plots in long-term is scarce (Dangi et al. 2010).

\section{Conclusions}

Extreme climate events leading to forest disturbances including windthrow and fire can be expected worldwide as a consequence of ongoing climate change. As they can affect also the environment of soil microorganisms after the disturbance, information about the changes in microbial community and time of its recovery can be very important as the soil microorganisms play the key role in nutrient cycles and their availability for plants. The present study showed that the absence of significant differences in microbial characteristics and a similarity of microbial community composition between the extracted and not-extracted plots persists ten years after the windthrow, despite the fact that a significant difference between plots in $\mathrm{C} / \mathrm{N}$ ratio appeared as a consequence of the input of the organic matter of different quality. A beneficial effect of the reduction of thick surface organic layers after wildfire and the consequent release of nutrients persists over a decade and is reflected in still higher microbial activity at the burnt plot in comparison to the other windthrow plots. Microbial characteristics at the "new" windthrow plot did not differ from the plots with different management, except the burnt plot. These results suggest that at a high elevation the regional mesoclimate has a deeper effect on soil microorganisms than different post-disturbance management regime (removing or leaving fallen trees), in contrast to a wildfire, whose distinct effect lasts longer than a decade.

\section{Acknowledgments}

We thank V. Kriššák, T. Dvorská and Z. Brnáková for technical and laboratory assistance. This study was financed by the projects APVV-15-0176, VEGA 1/0710/17 and VEGA $1 / 0783 / 15$.

\section{References}

Alef K (1991). Methodenhandbuch Bodenmikrobiologie. Aktivitäten, Biomasse, Differenzierung [Methodical manual for soil microbiology. Activities, biomass, differentiation]. Ecomed, Landesberg, Germany, pp. 284. [in German]

Bárcenas-Moreno G, García-Orenes F, MataixSolera J, Mataix-Beneyto J, Bååth E (2011). Soil microbial recolonisation after a fire in a $\mathrm{Me}$ diterranean forest. Biology and Fertility of Soils
47: 261-272. - doi: 10.1007/s00374-010-0532-2 Bormann BT, Spaltenstein $\mathrm{H}$, McClellan $\mathrm{MH}$, Ugolini FC, Cromack K, Nay SM (1995). Rapid soil development after windthrow in pristine forests. Journal of Ecology 83: 747-757. - doi: $10.2307 / 2261411$

Cerevková A, Renčo M, Cagán L (2013). Shortterm effects of forest disturbances on soil nematode communities in European mountain spruce forests. Journal of Helminthology 87: 376-385. - doi: 10.1017/So022149X12000508

Certini G (2005). Effects of fire on soil properties: a review. Oecologia 143: 1-10. - doi: 10.1007/ s00442-004-1788-8

Dangi SR, Stahl PD, Pendall E, Cleary MB, Buyer JS (2010). Recovery of soil microbial structure after fire in a sagebrush-grassland ecosystem. Land Degradation and Development 21: 423432.

Fleischer P (2011). Pokalamitný výskum vo Vysokých Tatrách - ciele, metódy a charakteristika lokalít [Postdisturbance research in High Tatra Mts. - aims, methods and site characteristics]. Štúdie o Tatranskom národnom parku 10: 7-12. [in Slovak]

Gömöryová E, Strelcová K, Fleischer P, Gömöry D (2011). Soil microbial characteristics at the monitoring plots on windthrow areas of the Tatra National Park (Slovakia): their assessment as environmental indicators. Environmental Monitoring and Assessment 174: 31-45. - doi: 10.1007/ s10661-010-1755-2

Gömöryová E, Strelcová K, Skvarenina J, Bebej J, Gömöry D (2008). The impact of windthrow and fire disturbances on selected soil properties in the Tatra National Park. Soil and Water Research 3: 574-580. [online] URL: http:// 81.0.228.28/public Files/01674.pdf

Hart SC, DeLuca TH, Newman SG, Mackenzie MD, Boyle SI (2005). Post-fire vegetative dynamics as drivers of microbial community structure and function in forest soils. Forest Ecology and Management 220: 166-184. - doi: 10.1016/j. foreco.2005.08.012

Hartmann A, Kobler J, Kralik M, Dirnbock T, Humer F, Weiler M (2016). Model-aided quantification of dissolved carbon and nitrogen release after windthrow disturbance in an Austrian karst system. Biogeosciences 13: 159-174. doi: 10.5194/bg-13-159-2016

Hedo J, Lucas-Borja ME, Wic C, Andrés-Abellán M, De Las Heras J (2015). Soil microbiological properties and enzymatic activities of longterm post-fire recovery in dry and semiarid Aleppo pine (Pinus halepensis M.) forest stands. Solid Earth 6: 243-252. - doi: 10.5194/se-6-2432015

Hill MO (1973). Diversity and evenness: a unifying notation and its consequences. Ecology 54: 427-432. - doi: $10.2307 / 1934352$

Holden SR, Treseder KK (2013). A meta-analysis of soil microbial biomass responses to forest disturbances. Frontiers in Microbiology 4: 163. doi: $10.3389 /$ fmicb.2013.00163

Holden SR, Rogers BM, Treseder KK, Randerson JT (2016). Fire severity influences the response of soil microbes to a boreal forest fire. Environmental Research Letters 11: 035004. - doi: 10.1088/1748-9326/11/3/035004

Homolová Z, Kyselová Z, Soltés R (2015). Dynamika vegetácie na kalamitných plochách $v$ spoločenstve Lariceto-Piceetum [Vegetation dynamics on post-disturbance plots in the Lariceto-Piceetum community]. Štúdie o Tatranskom národnom parku 11: 191-200. [in Slovak] Insam H (1997). A new set of substrates proposed for community characterization in environmental samples. In: "Microbial Communities. Functional versus Structural Approaches" (Insam H, Rangger A eds). Springer, Heidelberg, Germany, pp. 260-261. [online] URL: http://books.google.com/books?id=I1vrCAAAQB AJ

Islam KR, Weil RR (1998). Microwave irradiation of soil for routine measurements of microbial biomass carbon. Biology and Fertility of Soils 27: 408-416. - doi: 10.1007/s003740050451

Kandeler E (1993). Bestimmung der N-mineralisation im anaeroben Brutversuch [Determination of $\mathrm{N}$-mineralisation in an anaerobic cultivation experiment]. In: "Bodenbiologische Arbeitsmethoden” (Schinner F et al. eds). Springer Verlag, Berlin, Heidelberg, New York, pp. 160-161. [in German]

Khaziev FCH (1976). Fermentativnaja aktivnost' pochv [Enzymatic activity of soils]. Metodicheskoe posob'e, Moskva, Russia, pp. 262. [in Russian]

Knelman JE, Graham EB, Trahan NA, Schmidt SK, Nemergut DR (2015). Fire severity shapes plant colonization effects on bacterial community structure, microbial biomass, and soil enzyme activity in secondary succession of a burned forest. Soil Biology and Biochemistry 90: 161168. - doi: 10.1016/j.soilbio.2015.08.004

Knelman JE, Schmidt SK, Lynch RC, Darcy JL, Castle SC, Cleveland CC, Nemergut DR (2014). Nutrient addition dramatically accelerates microbial community succession. PLOS ONE 9 (7): e102609. - doi: 10.1371/journal.pone.0102609 Kooch Y, Hosseini SM, Samonil P, Hojjati SM (2014). The effect of windthrow disturbances on biochemical and chemical soil properties in the northern mountainous forests of Iran. Catena 116: 142-148. - doi: 10.1016/j.catena.2014.01. 002

Köster K, Jõgiste K, Tukia H, Niklasson N, Möls T (2005). Variation and ecological characteristics of coarse woody debris in Lahemaa and Karula National Parks Estonia. Scandinavian Journal of Forest Research 20: 102-111. - doi: 10.1080/1400 4080510042137

Köster K, Püttsepp U, Pumpanen J (2011). Comparison of soil $\mathrm{CO}_{2}$ flux between uncleared and cleared windthrow areas in Estonia and Latvia. Forest Ecology and Management 262: 65-70. doi: 10.1016/j.foreco.2010.09.023

Lang KD, Schulte LA, Guntenspergen GR (2009). Windthrow and salvage logging in an oldgrowth hemlock-northern hardwoods forest. Forest Ecology and Management 259: 56-64. doi: 10.1016/j.foreco.2009.09.042

Nielsen MN, Winding A (2002). Microorganisms as indicators of soil health. Technical Report No. 388, National Environmental Research Institute, Ministry of the Environment, Roskilde, Denmark, pp. 83. [online] URL: http://www. dmu.dk/1_Viden/2_Publikationer/3_Fagrapport er/rapporter/FR388.pdf

Peterson CJ, Leach AD (2008). Salvage logging after windthrow alters microsite diversity, abundance and environment, but not vegeta- 
tion. Forestry 81: 361-376. - doi: 10.1093/for estry/cpnoo 7

Reinhart KO, Royo AA, Kageyama SA, Clay K (2010). Canopy gaps decrease microbial densities and disease risk for a shade-intolerant tree species. Acta Oecologica 36: 530-536. - doi: 10.1016/j.actao.2010.07.006

Robertson GP, Crum JR, Ellis BG (1993). The spatial variability of soil resources following longterm disturbance. Oecologia 96: 451-456. - doi: 10.1007/BFo0320501

Rumbaitis Del Rio CM (2006). Changes in understory composition following catastrophic windthrow and salvage logging in a subalpine forest ecosystem. Canadian Journal of Forest Research 36: 2943-2954. - doi: 10.1139/x06-169

SAS (2010). SAS/STAT User's guide (release 6.03 edn). SAS Institute, Cary, NC, USA, pp. 1028.

Seidl R, Rammer W, Blennow K (2014). Simulating wind disturbance impacts on forest landscapes: tree-level heterogeneity matters. Environmental Modelling and Software 51: 1-11. doi: 10.1016/j.envsoft.2013.09.018

Ter Braak CJ, Smilauer FP (2002). CANOCO Reference manual and users guide to CANOCO for Windows. Software for canonical community ordination (version 4). Centre of Biometry,
Wageningen, Netherlands, pp. 353.

Thom D, Seidl R (2015). Natural disturbance impacts on ecosystem services and biodiversity in temperate and boreal forests. Biological Reviews of the Cambridge Philosophical Society 91: 760-781. - doi: 10.1111/brv.12193

Thürig E, Palosuo T, Bucher J, Kaufmann E (2005). The impact of windthrow on carbon sequestration in Switzerland: a model-based assessment. Forest Ecology and Management 210: 337-350. - doi: 10.1016/j.foreco.2005.02.030

Tscherko D, Kandeler E (1999). Classification and monitoring of soil microbial biomass, $\mathrm{N}$-mineralization and enzyme activities to indicate environmental changes. Die Bodenkultur 50: 215226.

Ulanova NG (2000). The effect of windthrow on forests at different spatial scales: a review. Forest Ecology and Management 135: 155-167. - doi: 10.1016/S0378-1127(00)00307-8

Urbanovičová V, Miklisová D, Kováč L (2014). Forest disturbance enhanced the activity of epedaphic collembolan in windthrown stands of the High Tatra mountains. Journal of Mountain Science 11: 449-463. - doi: 10.1007/s11629013-2736-z

Wardle DA, Bardgett RD, Klironomos JN (2004).
Ecological linkages between aboveground and belowground biota. Science 304: 1629-1633. doi: $10.1126 /$ science.1094875

Wright CJ, Coleman DC (2002). Responses of soil microbial biomass, nematode trophic groups, $\mathrm{N}$-mineralization, and litter decomposition to disturbance events in the southern Appalachians. Soil Biology and Biochemistry 34: 13-25. doi: 10.1016/S0038-0717(01)00128-6

Xu J, Xue L, Su Z (2016). Impacts of forest gaps on soil properties after a severe ice storm in a Cunninghamia lanceolata stand. Pedosphere 26: 408-416. - doi: 10.1016/S1002-0160(15)600534

\section{Supplementary Material}

Fig. S1 - Comparison of means of the $\mathrm{Cmic/}$ C, Resp/C and Resp/Cmic.

Tab. S1 - Average relative abundances of microbial groups utilizing Biolog substrates on individual plots.

Link: Gomoryova_2304@supplo01.pdf 